\title{
Health insurance enrollees' satisfaction with health maintenance organizations and non-enrollees' willingness to participate and pay for health insurance in Abuja, Nigeria
}

\section{Obembe Oluwagbemiga Oladipupo ${ }^{1}$, Abodunrin Olugbemiga Lanre ${ }^{2 *}$, Jegede S. Oluwatosin ${ }^{3}$}

\author{
${ }^{1}$ Impact Generation Teens to Adult, Initiatives, FCT, Nigeria \\ Department of Community Medicine, ${ }^{2}$ College of Health Sciences, Ladoke Akintola University of Technology, \\ ${ }^{3}$ Lautech Teaching Hospital, Ogbomoso, Oyo State, Nigeria
}

Received: 19 August 2017

Revised: 16 September 2017

Accepted: 18 September 2017

\section{*Correspondence:}

Dr. Abodunrin Olugbemiga Lanre,

E-mail: oabodunrin@lautech.edu.ng

Copyright: () the author(s), publisher and licensee Medip Academy. This is an open-access article distributed under the terms of the Creative Commons Attribution Non-Commercial License, which permits unrestricted non-commercial use, distribution, and reproduction in any medium, provided the original work is properly cited.

\begin{abstract}
Background: The Health Maintenance Organizations (HMO) which is shouldered with the responsibility of coordinating the activities of the Health Care Providers (HCP) to ensure good services are rendered to the insured enrollees have been reported to be failing in her responsibilities. This study was conducted to determine enrollees' satisfaction with HMOs services and the willingness of the non-insured to participate in health insurance scheme in Abuja Metropolis.

Methods: A cross-sectional study was conducted among 400 Health Insurance enrollees using systematic sampling method. Data were collected using self-administered semi-structured questionnaires and analyzed using the statistical package for social sciences (SPSS) version 20.

Results: This study revealed low satisfaction of enrollees with the services rendered by their HMOs as only a few above half of the study participants $115(54.8 \%)$ reported to have been satisfied with the services received from the health insurance administration, their service providers and the HMOs in charge.

Conclusions: Though Health Insurance is a proven way of achieving universal health coverage and Health for all populations, this study showed that enrollee's dissatisfaction with HMOs services has continually being a hindrance to this key Alma-Ata Declaration. More knowledge among enrollees about the modus operandi of HMOs will help them demand for better services as a right.
\end{abstract}

Keywords: Health maintenance organizations, Enrollee, Health insurance

\section{INTRODUCTION}

Health maintenance organizations (HMOs) may be defined as institutions that both insure and provide health care services to an enrolled population in exchange for pre-paid per capital payment. HMOs have become a viable sector of the medical economy and are potential significant vehicles for controlling health care costs. It is an organization that provides or arranges managed care for health insurance and acts as a liaison with health care providers (hospitals, doctors, etc.) on a prepaid basis. They are also to ensure adherence to quality services for their patients.

It is widely acknowledged that the performance of a national health system is largely determined by its financing and payment mechanism. ${ }^{1}$ It is therefore of little surprise that one of the most important policy goal 
and objective of a national health system is to secure a stable and sustainable ways and means by which funds are mobilized to pay for essential health services in equitable, fair and just manner, such that everyone is protected against the catastrophic and poverty induced effects of ill-health. ${ }^{2}$ Developing and implementing a sustainable healthcare financing strategy are key success factor for health sector reforms in Nigeria and in improving the health status of a majority of Nigerians. ${ }^{1,2}$

The NHIS scheme is designed to provide comprehensive health care delivery at without out-of-pocket expenditure; covering employees of the federal formal sector. ${ }^{3}$ The self-employed, as well as rural communities, the poor and the vulnerable groups are also provided with appropriate form of Health Insurance. There has been an increasing awareness in the function and modus operandi of health maintenance organization in Nigeria; however, the expectations of individuals are not always met as there are various challenges encountered in relationship management between HMO enrollees, Health maintenance organization and health care providers. ${ }^{4}$ Although businesses pursued the HMO model for its alleged cost containment benefits, some studies indicates that private HMO plans don't achieve any significant cost savings over non-HMO plans. Although out-of-pocket costs are reduced for consumers; controlling for other factors, the plans don't affect total expenditures and payments by insurers. A possible reason for this failure is that consumers might increase utilization in response to less cost sharing under HMOs. ${ }^{5}$ Some have asserted that HMOs actually increase administrative costs and tend to cherry-pick healthier patients. ${ }^{6}$ However, the beneficiary cost sharing (e.g., co-payment or coinsurance) may be higher for specialist care. ${ }^{7}$ Anecdotal evidences also showed that quite a number of enrollees do not even know their HMOs neither do they know what their rights and privileges are.

Public health system in Nigeria, have failed to deliver adequate level of services, especially to the disadvantage groups. ${ }^{8}$ The extent of coverage of the NHIS is such that artisans, farmers, sole proprietors of businesses, street vendors, traders and the unemployed are not yet adequately covered. It is hoped that this study will serve as an available reference source and will help other researchers in this field; thus contributing to the existing literature. Moreover, the study will help government and health maintenance organizations in policy formulation and administration for better service delivery and improvements in the scheme.

This study sought to assess the knowledge and satisfaction of enrollee of Health insurance with the health insurance scheme and the activities of the health maintenance organizations (HMOs) in Abuja Metropolitan Area Council, Abuja and well as nonenrollees' willingness to participate and pay for health insurance.

\section{METHODS}

The study was carried out in the Federal Capital Territory Abuja which is located in the centre of the country. It's administration is headed by a Minister appointed by the President of Nigeria. The estimated population was $1,405,201$. The Territory is made up of six Area Councils namely Abuja Municipal, Abaji, Bwari, Gwagwalada, Kuje and Kwali. The study population consists of the health care users in corporate organizations in Abuja Municipal Area Council above the age of eighteen 18 years.

The study was a cross-sectional descriptive study. An outpatient baseline user's utilization and satisfaction survey conducted in some selected NHIS accredited healthcare providers in the Northwest geo-political region of the country in 2008 by Diazenge showed that $65 \%$ of the users of these facilities were very satisfied with the services and this was used in calculating the sample size using the Leslie Fischer's formula. ${ }^{9}$ A total of 400 people participated in the study.

Sample size $(\mathrm{n}) \quad=\frac{z^{2} \mathrm{pq}}{d^{2}}$

The study was conducted in selected corporate companies within Abuja Metropolitan Area Council. A list of all registered corporate organizations was obtained. A systematic sampling technique was used where every 2 nd office listed was sampled until the desired sample size was obtained. The questionnaires were administered between January and March 2016, to the every person who met the inclusion criteria and consented to participate in the study in the offices selected.

The data collection instrument is a semi-structured questionnaire consisting of three sections - personal data, perception of and experience with HMOs as well as willingness to participate in and to pay for health insurance for non-insured respondents. Data were collected with the use of self-administered semistructured questionnaire. The internal consistency of the instrument was determined by a pretest on 20 health care consumers in Gwagwalada area council, Abuja. The data generated were analyzed both manually and by the use of statistical package for social sciences (SPSS) 20 software package. The data was presented in the form of tables, graphs and charts, while measures of central tendency (mean, median and mode) and measure of variability (standard deviation) were used where appropriate.

Informed consent was duly sought and obtained from research participants who volunteered to take part in the study. The research participants were assured of anonymity and confidentiality of information elicited. The study was conducted in only one area council in Abuja; therefore, it might be difficult to generalize findings. 


\section{RESULTS}

A total of 400 respondents within Abuja Municipal Area Council (AMAC) in the Federal Capital Territory (FCT) completed the questionnaire. Two hundred and sixty seven (66.7\%) were male while 133 (33.3\%) were female. The married were more $317(79.2 \%)$ than those who never married $83(20.8 \%)$. Among those that were married, most $147(46.4 \%)$ have between 1 and 4 children. Other variables are as in Table 1.

Table 1: Socio-demographic characteristics of respondents.

\begin{tabular}{|lll|}
\hline $\begin{array}{l}\text { Characteristics } \\
\text { Gender }\end{array}$ & $\begin{array}{l}\text { Frequency } \\
(\mathbf{N}=400)\end{array}$ & $\begin{array}{l}\text { Percentage } \\
(\%)\end{array}$ \\
\hline Male & 267 & 66.7 \\
\hline Female & 133 & 33.3 \\
\hline Marital status & & \\
\hline Single & 83 & 20.8 \\
\hline Married & 317 & 79.2 \\
\hline No of children (N=317) & & \\
\hline 0 & 16 & 5.0 \\
\hline $1-4$ & 147 & 46.4 \\
\hline$>4$ & 154 & 48.6 \\
\hline $\begin{array}{l}\text { Average monthly } \\
\text { income (N) }\end{array}$ & \\
\hline 50,000-100,000 & 212 & 53.0 \\
\hline 100,001 -250,000 & 149 & 37.3 \\
\hline 250,001-500,000 & 21 & 5.25 \\
\hline 500,001 - 1,000,000 & 12 & 3.00 \\
\hline$>1,000,000$ & 6 & 1.5 \\
\hline Educational category & & \\
\hline Secondary & 50 & 12.4 \\
\hline Tertiary & 175 & 43.8 \\
\hline Post graduate & 175 & 43.8 \\
\hline Religion & & \\
\hline Christianity & 204 & 51.0 \\
\hline Islam & 192 & 48.0 \\
\hline Traditional & 4 & 1.0 \\
\hline Employment status & & \\
\hline Private organization & 251 & 37.5 \\
\hline Government & 149 & 33.3 \\
\hline Retirement status & & \\
\hline Retired & 32 & 82.0 \\
\hline In active service & 368 \\
\hline
\end{tabular}

Table 2 describes the knowledge of respondents with respects to health insurance and HMOs from the various questions asked resulting into the sum knowledge. There is higher knowledge of health insurance scheme than HMOs. Only a few understand the modality of how the scheme works and the right to change either or both the HMO and the service provider. Three hundred and forty seven $(86.7 \%)$ of the respondent have knowledge on working modalities and benefits of health insurance.
Overall, only 101 representing $25.3 \%$ of the respondents have good knowledge of Health Insurance and operation of HMOs.

Table 2: Respondents' sum knowledge of health maintenance organizations and the health insurance scheme.

\begin{tabular}{|c|c|c|}
\hline Variable & $\begin{array}{l}\text { Frequency } \\
(\mathrm{N}=400)\end{array}$ & $\begin{array}{l}\text { Percentage } \\
(\%)\end{array}$ \\
\hline $\begin{array}{l}\text { Correctly describes what } \\
\text { HMO stands for }\end{array}$ & 162 & 40.5 \\
\hline $\begin{array}{l}\text { Correctly identifies the } \\
\text { role(s) of HMOs in } \\
\text { Health Insurance } \\
\text { scheme }\end{array}$ & 96 & 24.0 \\
\hline $\begin{array}{l}\text { Understands that he/she } \\
\text { has a right to change his } \\
\text { HMO }\end{array}$ & 41 & 10.2 \\
\hline $\begin{array}{l}\text { Understands that the } \\
\text { process/modality to } \\
\text { change HMO }\end{array}$ & 17 & 4.2 \\
\hline $\begin{array}{l}\text { Understands the benefits } \\
\text { of HIS }\end{array}$ & 289 & 72.2 \\
\hline $\begin{array}{l}\text { Understands the } \\
\text { process/modality of HIS }\end{array}$ & 92 & 23.0 \\
\hline $\begin{array}{l}\text { Understands the scope of } \\
\text { service coverage of the } \\
\text { chosen HIS }\end{array}$ & 134 & 33.5 \\
\hline $\begin{array}{l}\text { Understands he/she can } \\
\text { change his/her health } \\
\text { service provider under } \\
\text { insurance scheme }\end{array}$ & 91 & 22.7 \\
\hline $\begin{array}{l}\text { Understands that the } \\
\text { process/modality to } \\
\text { change service provider }\end{array}$ & 44 & 11.0 \\
\hline $\begin{array}{l}\text { Understands the referral } \\
\text { process with HIS }\end{array}$ & 47 & 11.7 \\
\hline \multicolumn{3}{|l|}{ Overall knowledge score } \\
\hline Good & 101 & 25.3 \\
\hline Poor & 299 & 74.7 \\
\hline
\end{tabular}

HIS: Health Insurance Scheme; HMO: Health Maintenance Organization.

Two hundred and ten $(52.5 \%)$ of respondents were enrolled on Health Insurance Scheme. Among those enrolled on the scheme, $117(55.7 \%)$ were using public health insurance scheme while $93(44.3 \%)$ were using private health insurance scheme. Majority 147 (70.0\%) have been enrolled for at least five years. The main factor for registration with insurance scheme is demand from workplace. A larger percentage of the respondents have their choice (between private and public health insurance) made for them by their employer. Of the respondents, $115(54.8 \%)$ reported to have been satisfied with the services received from the health insurance administration, their service providers and the HMOs in charge. The reasons why enrollee's expectations were not met to satisfaction include poor registration services, poor 
referral system, delay in receiving required services and unavailability of some required services. Out of 118 respondents that were not yet enrolled in a form of health insurance, $81(68.7 \%)$ prefer to contribute only $2 \%$ of their basic salary.

Table 3: Participation of respondents in health insurance scheme.

\begin{tabular}{|c|c|c|}
\hline Variable & Frequency & Percentage $(\%)$ \\
\hline \multicolumn{3}{|l|}{ Currently on health insurance scheme $(n=400)$} \\
\hline Yes & 210 & 52.5 \\
\hline No & 190 & 47.5 \\
\hline \multicolumn{3}{|l|}{ Types of health insurance scheme $(n=210)$} \\
\hline Private & 93 & 44.3 \\
\hline Public & 117 & 55.7 \\
\hline \multicolumn{3}{|l|}{ Duration of registration $(n=210)$} \\
\hline$<5$ years & 63 & 30.0 \\
\hline$\geq 5$ years & 147 & 70.0 \\
\hline \multicolumn{3}{|l|}{ Factors for registration $(n=210)$} \\
\hline Office & 125 & 59.5 \\
\hline Personal decision & 82 & 39.0 \\
\hline Association & 3 & 1.4 \\
\hline \multicolumn{3}{|l|}{ Reasons for choice $(\mathrm{n}=\mathbf{2 1 0})$} \\
\hline Office & 123 & 58.6 \\
\hline Personal decision & 84 & 40.0 \\
\hline Association & 3 & 1.4 \\
\hline Satisfaction with health insurance $(n=210)$ & 115 & 54.8 \\
\hline Willingness of non-enrollees to participate $(n=190)$ & 118 & 62.1 \\
\hline \multicolumn{3}{|l|}{$\begin{array}{l}\text { Willingness to pay for health insurance }(n=118) \\
\quad \text { Preference to contribute }\end{array}$} \\
\hline $1 \%$ of basic salary & 5 & 4.2 \\
\hline $2 \%$ of basic salary & 81 & 68.7 \\
\hline $5 \%$ of basic salary & 30 & 25.4 \\
\hline $7.5 \%$ of basic salary & 2 & 1.7 \\
\hline
\end{tabular}

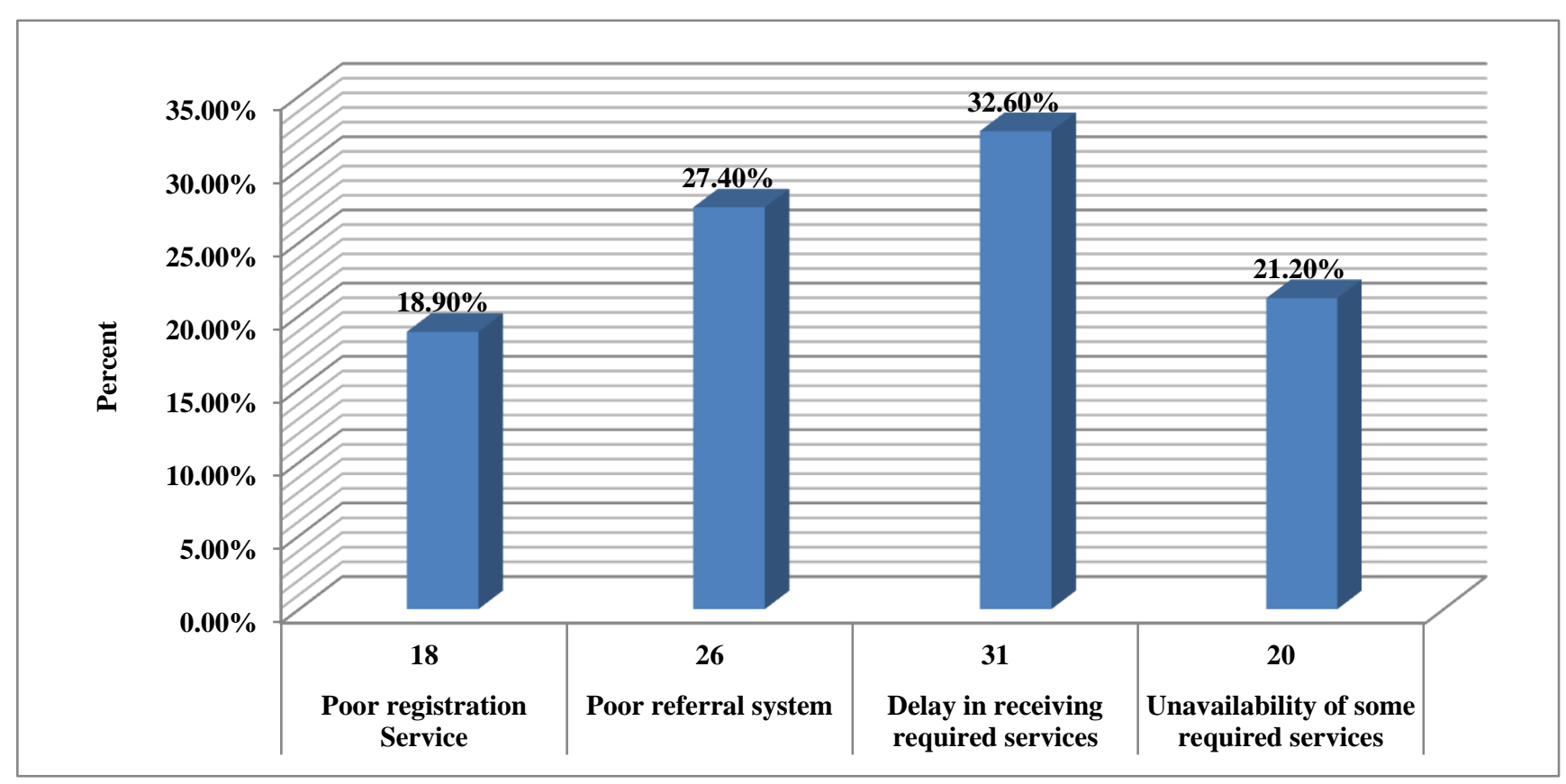

Figure 1: Reasons why expectations were not met.

Marital status, number of children, monthly income, educational status and employment status were all statistically associated with knowledge of health insurance but retirement status was not. Those who were 
enrolled in health insurance also have a higher knowledge than those who were not. Among the enrolled, the length of years of enrolment was statistically associated with their knowledge of HIS and HMOs but the type of health insurance was not associated.

Table 4: Association between selected socio-demographic characteristics and enrolment status and knowledge of health insurance scheme and health maintenance organizations.

\begin{tabular}{|c|c|c|c|c|c|c|}
\hline \multirow{2}{*}{ Variables } & \multicolumn{2}{|c|}{ HIS and HMO knowledge } & \multirow{2}{*}{$X^{2}$} & \multirow{2}{*}{ df } & \multirow{2}{*}{ P-value } & \multirow{2}{*}{ Remarks } \\
\hline & Good & No & & & & \\
\hline \multicolumn{7}{|l|}{ Marital status } \\
\hline Single & 5 & 78 & \multirow{2}{*}{20.511} & \multirow{2}{*}{1} & \multirow{2}{*}{$<0.0001$} & \multirow{2}{*}{$\begin{array}{l}\mathrm{p}<0.005 \text { Statistically } \\
\text { significant }\end{array}$} \\
\hline Married & 96 & 221 & & & & \\
\hline \multicolumn{7}{|c|}{ Category of no of children } \\
\hline 0 & 17 & 82 & \multirow{3}{*}{13.048} & \multirow{3}{*}{1} & \multirow{3}{*}{0.0018} & \multirow{3}{*}{$\begin{array}{l}\mathrm{p}<0.005 \\
\text { Statistically significant }\end{array}$} \\
\hline $1-4$ & 52 & 95 & & & & \\
\hline$>4$ & 32 & 122 & & & & \\
\hline \multicolumn{7}{|c|}{ Average monthly income(n) } \\
\hline $50,000-100,000$ & 3 & 27 & \multirow{4}{*}{20.730} & \multirow{4}{*}{3} & \multirow{4}{*}{0.0001} & \multirow{4}{*}{$\begin{array}{l}\mathrm{p}<0.005 \\
\text { Statistically significant }\end{array}$} \\
\hline $100,00-250,000$ & 55 & 94 & & & & \\
\hline $250,001-500,000$ & 25 & 78 & & & & \\
\hline$>500,000$ & 18 & 100 & & & & \\
\hline Educational category & 11 & 39 & & & & \\
\hline Secondary & 36 & 139 & \multirow{3}{*}{84.167} & \multirow{3}{*}{2} & \multirow{3}{*}{$<0.0001$} & \multirow{3}{*}{$\begin{array}{l}\mathrm{p}<0.005 \\
\text { Statistically significant }\end{array}$} \\
\hline Tertiary & 54 & 121 & & & & \\
\hline Post graduate & & & & & & \\
\hline \multicolumn{7}{|l|}{ Employment status } \\
\hline Private Organization & 67 & 184 & \multirow{2}{*}{52.282} & \multirow{2}{*}{2} & \multirow{2}{*}{$<0.0001$} & $\mathrm{p}<0.005$ \\
\hline Government & 34 & 115 & & & & Statistically significant \\
\hline Retirement status & & & & & & \\
\hline Retired & 8 & 24 & 0001 & 1 & 00770 & $\mathrm{p}>0.05$ Not \\
\hline In active service & 93 & 275 & 0.001 & 1 & 0.9129 & statistically significant \\
\hline Enrolment status & & & & & & \\
\hline Enrolled & 69 & 141 & 13551 & 1 & 00002 & Statictically cionificant \\
\hline Not enrolled & 32 & 158 & 13.551 & 1 & 0.0002 & stausticany signincant \\
\hline Type of enrolment (n & & & & & & \\
\hline Private & 31 & 62 & 0017 & 1 & 08058 & Not Statistically \\
\hline Public & 38 & 79 & 0.011 & 1 & 0.0950 & significant \\
\hline Length of enrolment & & & & & & \\
\hline$<5$ years & 27 & 36 & 4082 & 1 & 00434 & Staticticolly cimnificont \\
\hline$\geq 5$ years & 42 & 105 & 4.002 & 1 & 0.0454 & stausticany signilicant \\
\hline
\end{tabular}

One hundred and nine $(51.9 \%)$ of enrollee want health service providers to employ more staff for better service while $75(35.7 \%)$ want computerization of medical records, $72(34.3 \%)$ want a review of the referral system. Others want building of more infrastructure, training of existing staff, adequate funding and creation of separate health insurance unit.

\section{DISCUSSION}

HMOs and the national health insurance scheme have been in existence in Nigeria for a decade now. It was introduced in response to the dwindling funding of the nation health sector, with the aim of improving the quality of health services. Almost $80 \%$ of the respondents were married, while $20.7 \%$ were single, this is in line with the work of Sanusi and colleagues. ${ }^{10}$ Number of children in many of the households in this study is large which implies that most of the respondents have family sizes which cannot all be covered in the National Health Insurance Scheme as the scheme ordinarily cater for four children.

The knowledge of health insurance and HMOs is poor, just a little above a quarter of the participants have good knowledge; considering a scheme which has been in operation for more than a decade in the country and all the media publicity given to it. Although, majority of the studied population were well aware of health insurance, an observation which also observed in another in study conducted in Jos but lower than a similar study among civil servants in Osun State which revealed an awareness 
of $40 \%$, the in-depth understanding of the process and modalities is very poor both among the enrolled and the non-enrolled. ${ }^{11,12}$ It was not surprising though that those who were enrolled had better knowledge. Reasons for better knowledge of HIS and HMO among the private insured and government insured cannot be established. Studies of awareness and knowledge of HMOs is however scanty. This may be because the clients usually relates with only the health care provider but it is important for the people to know their rights and demand same as it relates with the HMOs. Many of the challenges some may even have with the providers may be due to the inefficiencies of their HMOs. When there is poor satisfaction with services of HMOs, the guideline provides for a change of HMOs once a year but very few knew this. As expected, the higher the educational level, the higher their knowledge of Health Insurance obviously due to their exposure and quest for knowledge.

Just a little more than half were registered with health insurance, an improvement over a similar study earlier report of $24 \%$ most of whom were government employees. ${ }^{13}$ More than $75 \%$ of public employees among the respondents in this study were enrolled on HIS compared with less than $40 \%$ of the private workers. This is not a good feature for a country after a decade of launching the scheme especially at a time of advocating for universal health coverage for the country. ${ }^{14,15}$ The government workers in the scheme were most likely there because it was mandatory and those yet to join are likely to be on the process though this study did not elicit that. Currently, most non-federal civil servants and private employees are yet to be registered with the scheme with the exception of two states out of 36 states of the federation. ${ }^{16}$ The same reason is responsible for low participation in private health insurance in comparison to NHIS which is a social form of health insurance. On the reason for choice of health insurance, it was observed that almost $60 \%$ of the respondent got enrolled based on the policy of their employer and not on their own. Most agencies of government has embedded the health insurance in the employment package of their staff, this is a welcome development however, individual opinions should be sort and understand their right before enrolling for a particular health insurance whether private or public. But the almost two thirds that showed interest in enrolling with the scheme is encouraging with a good proportion from the private employees.

The expectation of as much as $45 \%$ of the insured respondents were not met as compared to $26 \%$ that were dissatisfied in similar study by Onyedibe and collegues but less than the $57.9 \%$ reported in similar study by Salifu et al at Zaria in Kaduna state. ${ }^{11,17}$ The reasons why enrollees were dissatisfied with health insurance care services were also reported in other studies. ${ }^{18,19}$ It had been expected that enrolling in health insurance scheme would improve quality of services and clients satisfaction following the guidelines that established the health insurance including reducing waiting time and improving access to needed drugs but it was not so in this study. ${ }^{3,20}$ Challenges with registration processes, referral procedure and non-availability of drugs still persist. Some of the respondents who have complained of their predicaments to the service providers also gave an indirect report of the complaints of the providers who also had trouble with the HMOs by not providing the required capitation and this made the rendered services come below expectations.

It was also observed that the dissatisfaction was higher among respondents with public than private health insurance. Though, private health insurance is not as widespread as the public/social health insurance, their services seemed to be more client-friendly and satisfying probably because of less bureaucracy and waiting time. ${ }^{21}$ It may also not be unconnected to patient load which may be more with the social health insurance scheme. Registering with public or private insurance does not necessarily mean that the health care would be corresponding public and private but it usually happened that way as it was in this study.

\section{CONCLUSION}

HMO in collaboration with the national health insurance scheme in Nigeria is unarguably an indispensible strategy for ameliorating the poor health indices of the country and reducing out-of-pocket expenditure for quality health care services. This study reported a low level of awareness about the health maintenance organisations and high expectations from those enrolled.

\section{Recommendations}

It is therefore recommended that HMOs should be closely supervised and monitored that they ensure prompt remittance of capitations to the service providers. More multifaceted enlightenment of the enrollees is important to achieve the intended quality of service in terms of procedure to change service providers and HMOs who performs poorly while such service providers and HMOs investigated for reports against them with appropriate sanctions if found guilty. Such complaint section should be available in every centre providing services or as near as possible and not only at NHIS offices which might involve too long bureaucracy. Users themselves should seek knowledge and update themselves continually. The private insurance should also be strengthened the more while expanding services covered currently by the NHIS.

\section{ACKNOWLEDGEMENTS}

We appreciate the managers and staffers of the organizations used during this research for their full cooperation.

\author{
Funding: No funding sources \\ Conflict of interest: None declared \\ Ethical approval: The study was approved by the \\ Institutional Ethics Committee
}




\section{REFERENCES}

1. Campbell PC. Essential of Health Management Planning and Policy, University of Lagos Press, Lagos, Nigeria; 2007: 18-22.

2. Welcome MO. The Nigerian health care system: need for integrating adequate medical intelligence and surveillance systems. J Pharm Bioallied Sci. 2011;3(4):470-8.

3. NHIS Operational Guidelines. Available on www.nhis.gov.ng/index.php. Accessed on 13 July 2017.

4. Ibiwoye A, Adeleke A. The impact of health insurance on healthcare provision in developing countries. Ghana J Development Studies. 2007;4(21):49-58.

5. Shin J, Moon S. Do HMO Plans Reduce Expenditure in the Private Sector? Economic Inquire, 2007.

6. Physicians for a National Health Program. Claim that HMO's Save Money is Little More Than "Folklore," Health Affairs Study Finds 2000 Available at: http://www.pnhp.org/news/2000/ march/claim_that_hmos_sav.php. Accessed on 3 July 2017.

7. Kongstvedt PR. The Managed Health Care Handbook," Fourth Edition, Aspen Publishers Inc.; 2001: 40.

8. Lecky MM. A Ten Year Development Plan for Health:Healthcare Financing and National Health Insurance Scheme, 2006.

9. Diazenge D. Workshop: Towards a consumer assessment of health plan surveys (CAHPS) in Europe? Taking surveys of patient experience one step further. Netherland Institute Health Res Utrecht, the Netherlands.

10. Sanusi RA, Awe AT. Perception of National Health Insurance Scheme (NHIS) by Health Care Consumers in Oyo State, Nigeria. Pakistan J Social Sci. 2009;6(1):28-53.

11. Onyedibe KI, Goyit MG, Nnadi NE. An evaluation of the national Health Insurance Scheme (NHIS) in Jos, a North-central Nigerian City. Global Advanced Res J Microbiol. 2012;1(1):5-12.

12. Olugbenga-Bello AI, Adebimpe WO. Knowledge and attitude of Civil servants in Osun -State,
Southwestern Nigerian towards National health insurance. Niger J Clin Pract. 2010;13(4):421-6.

13. Osuchukwu NC, Osonwa KO, Eko JE, Uwanede CC, Abeshi SE, Offiong DA. Evaluating the Impact of National Health Insurance Scheme on Health Care Consumers in Calabar Metropolis, Southern Nigeria. Int J Learning Development. 2013;3(4):3045.

14. Sambo MN, Idris SH, Bashir SS et al:Financial hardship in settling medical bills among households in a semi-urban community in northwest Nigeria. West Afr J Med. 2013;32(1):14-8.

15. World Health Organization. Universal Health Coverage Day. Promoting health through the lifecourse. WHO.

16. Agba A, Ushie E, Osuchukwu N. National Health Insurance Scheme (NHIS) and Employees' Access to Healthcare Services in Cross River State, Nigeria. Glob J Hum Soc Sci. 2010;10:9-16.

17. Mohammed S. Understanding client satisfaction with a health insurance scheme in Nigeria: factors and enrollees experiences.

18. Babatunde OA, Akande TM, Salaudeen AG Aderibigbe SA, Elegbede OE, Ayodele LM. Willingness to pay for community health insurance and its determinants among household heads in rural communities in North-central Nigeria. Int Rev Social Sci Humanities. 2012;2(2):133-42.

19. Lawan UM, Iliyasu Z, Daso AM. Challenges to the scale-up of the Nigerian National Health Insurance Scheme: Public knowledge and opinions in urban Kano, Nigeria. Ann Trop Med Public Health. 2012.

20. National Health Insurance Scheme Decree No 35 of 1999.

21. Abodunrin OL, Bamidele JO, Olugbenga-Bello AI, Parakoyi DB. Preferred Choice of Health Facilities for Healthcare among Adult Residents in Ilorin Metropolis, Kwara State, Nigeria. Int J Health Res. 2010;3(2):77-86.

Cite this article as: Obembe OO, Abodunrin OL, Jegede SO. Health insurance enrollees' satisfaction with health maintenance organizations and nonenrollees' willingness to participate and pay for health insurance in Abuja, Nigeria. Int J Community Med Public Health 2017;4:3976-82. 